\title{
Assessing stability motor skills of five-to-six-year old and six-to- seven-year old obese children
}

\author{
Eka Oktavianingsih *, Asih Nur Ismiatun \\ Universitas Trunojoyo Madura. Jalan Raya Telang, Kabupaten Bangkalan, Jawa Timur 69162, Indonesia \\ * Corressponding Author. Email: eka.oktavianingsih@trunojoyo.ac.id
}

Received: 1 April 2020; Revised: 19 April 2020; Accepted: 6 May 2020

\begin{abstract}
This study aims to determine the differences in the stability motor skills between five-tosix-year old and six-to-seven-year old obese children. A total of 30 obese children were involved as the participants including 15 children aged 5-6 years old and 15 children aged 6-7 years old. Paediatric Balance Scale (PBS) was used to measure the stability motor performance of all participants. The method of data analysis was by means of independent sample T-test with a P value of 0.05 as the criterion for all statistical significance. The findings of this study revealed that there is a significant difference in stability motor skills in the parameter walking in a bearn, standing with one foot, and axial movement between five-to-six-year old and six-to-seven-year old obese children. Obese children aged 6-7 years old performed a better stability motor skills compared those aged 5-6 years old.
\end{abstract}

Keywords: stability motor skills, obese children, PBS, 5-6 years old, 6-7 years old.

How to Cite: Oktavianingsih, E., \& Ismiatun, A. (2020). Assessing stability motor skills of five-to-six-year old and six-to-seven-year old obese children. JPPM (Jurnal Pendidikan dan Pemberdayaan Masyarakat), 7(1), 16-22. doi:https://doi.org/10.21831/jppm.v7i1.31004

\section{INTRODUCTION}

Obesity among children is the most serious problem occuried in $21^{\text {st }}$ century (Sahoo et al., 2015). This problem occured in many countries with middle or low rate income, especially in Asia-Pacific including Indonesia, Malaysia, and China. In Indonesia, it has increased for the last two decades (Rachmi, Li, \& Alison Baur, 2017). Data from the Agency for Health Research and Development, Ministry of Health showed that $18.8 \%$ of children aged 5 to 12 years old in Indonesia have been categorized as obese (Ministry of Health, 2013). Obese children (age 5 to 10) will experience a decrease in motor skills, especially in gross motor skills when compared to children with a normal weight (Cheng et al., 2016).

Gross motor development is a skill to use the large muscles to maintain the balance and control of the body or locomotor (Mendleco, 2004). It includes the movement of the whole limbs or most parts of the body (Gordon \& Browne, 2008). Early childhood is the most crucial period of gross motor development (Gallahue \& Donnelly, 2003). One of the skills that the child has to control is the stability motor skill that involves the balance of the body in situations both of static and dynamic movements including balance with one leg, walking on the board of the catwalk, and axial movement (Gallahue, Ozmun, \& Godway, 2012). At preschool age, the balance is an important role in the performance of some basic motor skills (De Oreo \& Keogh, 1980; Shumway-Cook \& McCollum, 1991; Ulrich \& Ulrich, 1985; Venetsanou \& Kambas, 2011). The mastery of certain fundamental movements such as stability motor skill is a requirement if children want to engage in daily activities and participate in a continued physical activity or some special sporting activities.

One of the major developmental tasks of early age is physical growth and development. There is no other time in life that has increased rapidly in motor development except in early childhood (Allen \& Marotz, 2010; Essa, 2014: 250). Critical age in children whose motor skills increase rapidly occurs at the age of 2 to 7 years with the ideal age of 3 or 4 years (Sanders, 1992; 


\section{JPPM (Jurnal Pendidikan dan Pemberdayaan Masyarakat), 7 (1), 2020 - 17}

Eka Oktavianingsih, Asih Nur Ismiatun

Liu, Hamilton, \& Smith, 2015). Developing motor skills during early years is essential to equip the child's basic skills needed later in life as physically active adults with adjustable environmental motor skills (Stodden et al., 2008). Gross motor development will increase with the age of the child. Research conducted by Iivonen \& Sääkslahti (2013) showed that motor skills consisting of multiple domains would follow the age trend. In other words, the older children showed more ability in motor skills compared to their younger counterparts. Age becomes a significant factor for stability skills such as since the child was born until when a child can master a walking ability, and then at 6-7 years old children will begin to develop balance as in adults (Venetsanou \& Kambas, 2011; Nolan et.al, 2005).

In preschool age, stability motor skill is at an adequate level when the development will be perfect by the end of childhood (Venetsanou \& Kambas, 2011). One of the variables that affect the level of stability motor skills is the age of the child. Previous studies have suggested that obese children aged 6-8 years have the worse motor skills (locomotor ability and object control) in comparison to the obese children aged 4 to 6 years (Khalaj \& Amri, 2014). However, in particular the difference in the skills to stability between obese children of different ages has not been fully studied. Therefore, the purpose of this study was to prove the stability skill of obese children of different ages and to determine whether there was a difference in the skill to stability between two different age groups.

\section{METHOD}

\section{Design and Participants}

This current study employed a quantitative approach based upon a comparative design whose aim is to compare the similarities and differences among two or more characteristics of objects studied. The comparative design was called expost facto conducted after occurrence studied was passed. Fifteen obese children aged 5-6 years old and fifteen older obese children aged 6-7 years old were selected from many preschools and elementary schools in Bantul and Purbalingga. In Bantul, 3 preschools and 3 elementary schools were involved in this study, with each sample from school was 3 children. In Purbalingga, 2 preschools and 2 elementary schools became participants, each of them was 3 children. These samples were randomly taken in preschools and elementary schools that have obese children. Parents and teachers were asked whether they could give permissions for their children to participate in this study. Children whose parents and teachers did not agree with conducting experiment, were excluded from the participation.

\section{Measurement}

\section{Anthropometric Measurement}

Each participant's age, height, and weight of all participants was measured by investigators. It aimed to determine the Body Mass Index (BMI). Body Mass Index was counted on the basis of the body weight and body length measurements. The weight of children was measured by means of a digital scale. When their weight was measured, children removed their shoes and heavy clothes and they stood with both feet in the centre of the scale. Height measurement was placed on the floor without any carpet, so the measurement process could be more accurate. BMI was calculated with a pattern using weight $(\mathrm{kg})$ divided by height squared $\left(\mathrm{m}^{2}\right)$ and converted into BMI z-scores and percentiles for age and sex which obese was defined by $\mathrm{BMI} \geq 95^{\text {th }}$ percentile. The anthropometrics data of children was classified according to the BMI scale adapted by Cole, Bellizzi, Flegal, \& Dietz (2000).

\section{Stability Motor Assessment}

The Paediatric Balance Scale modified by Franjoine, Gunther, \& Taylor (2003) was used to assess the stability motor skills for children. It is a measurement including 14 test items (sitting to standing, standing to sitting, transfers, standing unsupported, sitting unsupported, standing 
with eyes closed, standing with feet together, standing with one foot in front, standing on one foot, turning 360 degrees, turning to look behind, retrieving object from floor, and placing alternate foot on stool). Paediatric Balance Scale (PBS) has good realibility and validity based on research by Craddock, Shen \& Monti (2015) using inter-rater, retest-test, and intra-reter.

In this study, the instrument was used to determine the stability motor skills of children aged between 5 years 2 months and 6 years 10 months. Each skill demonstrated the criteria describing the children performance on the skills, each of which varied in number from zero to four explaining various stability motor performances (14 tests). Children would get a score of four if performing the task correctly and perfectly. After assessing the children performance in stability motor skills, the crude scores of each skill were obtained by taking the best score of the criterion of two trials.

The test occured from September 2018 to October 2018. All measurements were executed in the afternoon, after the end of class by a principal investigator. Data collection firstly was conducted by demonstrating the every test and giving instructions for the participants how to perform each test on the stability motor skills. The demonstration was given once to avoid any helps from the investigators. Every participant was asked to perform each skill twice. A video camera placed in a proper position was used to record the performance of participants.

Statistical Analysis

In this study, data analysis involved a descriptive analysis and an Independent Sample Ttest. Mean and standard deviation were calculated for each variable. Independent Sample T-test was used to determine the age difference of stability motor skills between two groups of obese children and to determine the three types (i.e.walking on bearn, standing with one foot, and axial movement) of stability motor skills in two groups of obese children. All analyses of this study used SPSS (version 17), and the results were considered significant if less than 0.05 .

\section{FINDINGS AND DISCUSSION}

Anthropometrics data of all participants are presented in Table 1. 26.67\% participants in this study were girls and $73.33 \%$ were boys. The age and the age differences (chronological ageage equivalent) were presented in years. Researchers defined age differences to perform whether the children stability motor skills performance was superior or inferior according to normative samples from the Paediatric Balance Scale-guidance.

In this study, Table 1 presents the chronological age and age equivalent of stability motor skills among obese children.

Table 1. Anthropometrics data of all the participants.

\begin{tabular}{|c|c|c|c|c|}
\hline \multirow{2}{*}{ Criteria } & \multirow{2}{*}{ Age Group } & \multicolumn{3}{|c|}{ Obese } \\
\hline & & Min & Max & Mean (SD) \\
\hline \multirow[t]{2}{*}{ Chronological Age(years) } & 5-6 years & $5 \cdot 33$ & 5.83 & 5.34 \\
\hline & 6-7 years & 6.41 & 7.00 & 6.83 \\
\hline \multirow[t]{2}{*}{ Height $(\mathrm{cm})$} & 5-6 years & 108 & 127 & 118.2 \\
\hline & $6-7$ years & 110 & 135 & $124 \cdot 5$ \\
\hline \multirow[t]{2}{*}{ Weight (kg) } & 5-6 years & 25 & 33 & 29.93 \\
\hline & $6-7$ years & 34 & 47 & 39.67 \\
\hline \multirow[t]{2}{*}{ BMI } & 5-6 years & $19 \cdot 44$ & $25 \cdot 51$ & 21.43 \\
\hline & $6-7$ years & 20.75 & 33.06 & 25.95 \\
\hline
\end{tabular}

The results of Independent sample T-test for stability motor skills including walking on bearn, standing with one foot, and axial movement are presented in Table 2 . The result showed a different score in stability motor skills between five-to-six-year old and six-to-seven-year old obese children. Independent sample T-test results for stability motor skills in children aged 5-6 years old $(M=37.20, S D=3.448)$; in children aged 6-7 years old $(M=44.60, S D=2.063)$. According 
to presented results, it showed that obese children aged 6-7 years old had the better stability motor skills than obese children aged 5-6 years old.

Table 2. Results of t-test for stability motor skills between 5-6 year and 6-7 year obese children.

\begin{tabular}{llllll}
\hline & Age Group & $\mathrm{N}$ & Mean & Std. Deviation & Std. Error Mean \\
\hline \multirow{2}{*}{ Results of t-test } & $5-6$ years old & 15 & 37.20 & 3.448 & .890 \\
\cline { 2 - 6 } & $6-7$ years old & 15 & 44.60 & 2.063 & .533 \\
\hline
\end{tabular}

The results of Independent sample T-test for comparing two groups viewed from three types of stability motor skills (i.e. walking on bearn, standing with one foot, and axial movement) are presented in Table 3. Obese children aged 5-6 years old $(\mathrm{M}=2.93)$ had more deficit skills than obese children aged 6-7 years old $(M=3.67)$ in walking on bearn. Furthermore, obese children aged 5-6 years old $(M=2.46)$ had found less skilled compared to their older counterparts $(M=2.91)$ in standing with one foot. The last, obese children aged 5-6 years old ( $M=2.93)$ also had the worse skills than obese children aged 6-7 years old $(M=3.67)$ in axial movement. $P$ value from three aspects of stability motor skills was less than 0.05 including walking in a bearn $(\mathrm{P}=0.001)$, standing with one foot $(\mathrm{P}=\mathrm{o} .000)$, and axial movement (o.ooo). It means that the differences among two groups in stability motor skills were significant.

Table 3. Result of independent sample t-test for walking in a bearn, standing with one foot and axial movement between 5-6 year and 6-7 year old obese children.

\begin{tabular}{lllll}
\hline Aspects & Obese 5-6 children & Obese 6-7 children & F & P \\
\hline Walking in a bearn & & & & \\
Mean & 2.9333 & 3.6667 & .331 & .001 \\
SD & .59362 & .48795 & & \\
Standing in one foot & & & & \\
Mean & 2.4667 & 2.9167 & .346 & .000 \\
SD & .29681 & .20412 & & \\
Axial movement & & & & \\
Mean & 2.8133 & 3.2500 & .189 & .000 \\
SD & .22949 & .18292 & & \\
\hline
\end{tabular}

A research by Khalaj \& Amri (2014) explained that preschool obese children performed gross motor skills better as compared to those in early elementary school. According to results of that study, the measurement was conducted in gross motor skills including object control skills and locomotor skills of two group obese children. Object control skills were performed better than locomotor skills by all obese participants although the difference was little. However, skill of gross motor skills especially stability motor skills was not measured yet.

Early childhood is a period in which many development aspects increase quickly like that gross motor skills. In the last decades, there have been many studies investigating relationship between obese children and gross motor skills. The preschool children are classified as overweight or obese may have lower motor skills than their normal weight and under- weight peers (Logan, Scrabis-fletcher, Modlesky, \& Getchell, 2011). It shows a direct relationship between motor skills and Body Mass Index (BMI) in the preschool population. Unfortunately, there is a lack of study supporting the findings that investigated the difference among obese children in the different ages.

The present study aims to investigate the difference of stability motor skills among two age groups of obese children. Nevertheless, a study conducted by Deforche et al. (2009) showed that when children were categorised by the Body Mass Index (BMI), obese children displayed a lower capacity in several static stabilities and dynamic stabilities compare to the normal-weight children. Therefore, the present study showed the two groups of obese children with the different age. Age significantly effects on the stability motor skills in two groups of obese children. This may be due to the maturity factor based on Venetsanou \& Kambas (2011) in which age becomes one significant factor for preschooler's performance in stability motor skills, but gender is not related. 
The proofs that children aged 6-7 years old have been better in stability motor skills than the children aged 5-6 years old is found in many studies. The result of a study conducted by Jiang et al. (2017) demonstrated that stability motor skills (static or dynamic) between the three age groups (3-6 years old) showed some significant differences, which indicated that children's stability motor skills were significantly better in older groups. Similar results were obtained by other studies, Nolan et al., (2005) found that children around the age of 6 to 7 years begin to develop adult-like in stability motor skills. In addition, Mickle, Munro, \& Steele (2011) concluded that the most significant transitions in motor development occur in the first decade of life with stability motor skills usually established between the ages of 7-10 years. The findings of present study are in step with the results of previous studies, which reveal the better stability motor skills performance in children aged 6-7 years old than children aged 5-6 years old.

In addition to the maturity factor, stability motor skill is also supported by some physical activities. Studies have suggested that higher physical activities are related to the better motor skills (Sääkslahti, Numminen, Niinikoski, Rask-Nissilä, Viikari, Tuominen, et al., 1999 ; Williams, Pfeiff er, O'Neill, Dowda, McIver, Brown, et al., 2008 ; Cliff, Okely, Smith, \& McKeen, 2009) including stability, locomotor, and manipulative (Gallahue \& Cleland-Donnelly, 2003; Gallahue, Ozmun, \& Goodway, 2011; Iivonen et al., 2013). Unfortunately, obese children had the distinct patterns of physical activities bouts compared to the normal weight children in terms of duration spent in one day indicating that obese children have a fewer time for physical activities compared to the children with normal weight (Dorsey, Herrin, \& Krumholz, 2011). The difference in stability motor skills between obese children aged 5-6 years old and aged 6-7 years old could be because of the distinctiveness in maturity and the level of physical activities.

In the present study, children were tested in small sample size of two groups of obese children. It may give an impact on the findings which makes it difficult to generalize to the entire population of obese children. Further research would be valuable if it will be used in a larger sample of obese children. This study also did not explore the quality of each skill of stability motor skills describing what level that all children were reached. Furthermore, another possible factor including children's tenses when the tests were demonstrated also became the shortage of this study.

\section{CONCLUSION}

Gross motor skills in children including stability, locomotor, and manipulative are important to be identified as early as possible. Knowing the deficit of stability motor skills in obese children will help the parents and teachers in developing programs that foster those skills appropriately. Through this study, the differences of stability motor skills among two groups of obese children have been investigated. The results of this study emphasized that obese children aged 5-6 years old are easier in stability delays caused by obesity, maturity, and physical activities.

\section{REFERENCES}

Centers for Disease Control and Prevention (CDC). (2010). Overweight and obesity: Childhood overweight and obesity. Retrieved from http://www.cdc.gov/ obesity/childhood/index.html.

Cheng, J., East, P., Blanco, E., Kang Sim, E., Castillo, M., Lozoff, B., \& Gahagan, S. (2016). Obesity leads to declines in motor skills across childhood. Child: Care, Health and Development, 42(3), 343-350. https://doi.org/10.1111/cch.12336.

Cliff, D. P., Okely, A. D., Smith, L. M., \& McKeen, K. (2009). Relationships between fundamental movement skills and objectively measured physical activity in preschool children. Pediatric Exercise Science, 21(4), 436-449.

Cole, J., Bellizzi, M. C., Flegal, K. M., \& Dietz, W. H. (200o). Establishing a standard definition 
for child overweight and obesity worldwide: international survey, 320(7244), 1240-1240. https://doi.org/10.1136/bmj.320.7244.1240.

Craddock, D., Shen., \& Monti. G. (2015). Anticipatory balance in children with celebral parsly: A new tool for community based practice. Research Report Poster Presentation, 101, 16. https://doi.org///dx.doi.org/10.1016/j.physio.2015.03.464.

Deforche, B. I., Hills, A. P., Worringham, C. J., Davies, P. S. W., Murphy, A. J., Bouckaert, J. J., \& Bourdeaudhuij, I. M. D. E. (2009). Balance and postural skills in normal-weight and overweight prepubertal boys. International Journal of Pediatric Obesity, 4, 175-182. https://doi.org/10.1080/17477160802468470.

Dorsey, K. B., Herrin, J., \& Krumholz, H. M. (2011). Patterns of moderate and vigorous physical activity in obese and overweight compared with non-overweight children. International Journal of Pediatric Obesity, (April 2010), 547-555. https://doi.org/10.3109/17477166.2010.490586

Essa, E.L. (2014). Introduction to early childhood education. Cengage: Singapore.

Franjoine, M. R., Gunther, J. S., \& Taylor, M. J. (2003). Pediatric balance scale: A modified version of the berg balance scale for school-age child with mild to moderate motor impairment. Pediatric Physical Therapy.

Gallahue, D.L., \& Cleland-Donnelly, F. (2003). Development physical education for all children. Campaign, IL: Human Kinetics.

Gallahue, D.L., Ozmun, J.C., \& Goodway, J. (2012). Understanding motor development: Infants, children, adolescent, adults. New York: McGraw-Hill.

Gordon, A.M. \& Browne, K.W. (2008). Beginnings and beyond: Foundations in early childhood education. Australia: Cengage Learning.

Iivonen, K. S., Sääkslahti, A. K., Mehtälä, A., Villberg, J. J., Tammelin, T. H., Kulmala, J. S., \& Poskiparta, M. (2013). Relationship between fundamental motor skills and physical activity in 4-year-old preschool children. Perceptual and Motor Skills, 117, 627-646. https://doi.org/10.2466/10.06.PMS.117X22Z7

Jiang, G., Jiao, X., Wu, S., Ji, Z., Liu, W., \& Wang, H. (2017). Balance, proprioception, and gross motor development of Chinese children aged 3 to 6 years. Journal of Motor Behavior. https://doi.org/10.1080/00222895.2017.1363694

Khalaj, N., \& Amri, S. (2014). Mastery of gross motor skills in preschool and early elementary school obese children. Early Child Development and Care, 184(5), 37-41. https://doi.org/10.1080/03004430.2013.820724

Liu, T., Hamilton, M., \& Smith, S. (2015). Motor proficiency of the head start and typically developing children on MABC-2. Journal of Child and Adolescent Behavior, 3(2), 2-5. https://doi.org/10.4172/2375-4494.1000198

Logan, S. W., Scrabis-fletcher, K., Modlesky, C., \& Getchell, N. (2011). The relationship between motor skill proficiensy and Body mass Index in preschool children. Research Quarterly for Excercise and Sport, 82(3), 442-448.

Mickle, K. J., Munro, B. J., \& Steele, J. R. (2011). Gender and age affect balance performance in primary. Journal of Science and Medicine in Sport, 14(3), 243-248. https://doi.org/10.1016/j.jsams.2010.11.002.

Ministry of Health. (2013). Basic research of health. Indonesian Ministry of Health.

Nolan, L., Grigorenko, A., \& Thorstensson, A. (2005). Balance control: Sex and age differences in 9- to 16-year-olds. Developmental Medicine \& Child Neurology, (1987), 449-454.

Rachmi, C. N., Li, M., \& Alison Baur, L. (2017). Overweight and obesity in Indonesia: prevalence and risk factors-a literature review. Public Health, 147, 20-29. https://doi.org/10.1016/j.puhe.2017.02.002. 
JPPM (Jurnal Pendidikan dan Pemberdayaan Masyarakat), 7 (1), 2020 - 22

Eka Oktavianingsih, Asih Nur Ismiatun

Rudd, J. R., Barnett, L. M., Butson, M. L., Farrow, D., Berry, J., \& Polman, R. C. J. (2015). Fundamental movement skills are more than run, throw and catch: The role of stability skills. PLoS ONE, 1-15. https://doi.org/10.1371/journal.pone.0140224

Sahoo, K., Sahoo, B., Choudhury, A. K., Sofi, N. yasin, Kumar, R., \& Bhadoria, A. S. (2015). Childhood obesity: causes and consequences. Journal of Family Medicine and Primary Care, 4(2), 187-192. https://doi.org/10.4103/2249-4863.154628

Stodden, D. F., Goodway, J. D., Stephen, J., Roberton, M. A., Rudisill, M. E., Garcia, C., \& Garcia, L. E. (2008). A developmental perspective on the role of motor skill competence in physical activity: An Emergent Relationship. Quest, (May 2013), 37-41. https://doi.org/10.1080/00336297.2008.10483582

Venetsanou, F., \& Kambas, A. (2011). The effect of age and gender on balance skills in preschool children. Physical Education and Sport, 9(1), 81-90. 